\begin{tabular}{|l|l|l|}
\hline \multicolumn{2}{|c|}{ PublisherInfo } \\
\hline \hline PublisherName & $:$ & BioMed Central \\
\hline \hline PublisherLocation & $:$ & London \\
\hline \hline PublisherImprintName & $:$ & BioMed Central \\
\hline \hline
\end{tabular}

\title{
T cell gene expression profiles
}

\begin{tabular}{|l|l|l||}
\hline \multicolumn{2}{|c|}{ ArticleInfo } \\
\hline \hline ArticleID & $:$ & 206 \\
\hline \hline ArticleDOI & $:$ & $10.1186 /$ ar-2000-66782 \\
\hline \hline ArticleCitationID & $:$ & 66782 \\
\hline \hline ArticleSequenceNumber & $:$ & 163 \\
\hline \hline ArticleCategory & $:$ & Paper Report \\
\hline \hline ArticleFirstPage & $:$ & 1 \\
\hline \hline ArticleLastPage & $:$ & 3 \\
\hline \hline & & RegistrationDate : 2000-2-18 \\
\hline ArticleHistory & $:$ & OnlineDate \\
\hline \hline ArticleCopyright & $:$ & Current Science Ltd2000-2-18 \\
\hline \hline ArticleGrants & $:$ & \\
\hline \hline ArticleContext & $:$ & 130753311 \\
\hline \hline
\end{tabular}


Aff1 Royal Hallamshire Hospital, Sheffield, UK

\section{Keywords}

\section{Context}

Understanding the differences in gene expression patterns between resting and activated $\mathrm{T}$ cells may give important information about the regulation of these cells in health and disease. Several techniques have been used previously including subtraction techniques, differential display and gene arrays using $\mathrm{T}$ cells cultured ex vivo. This study involves the use of microchip technology to determine the expression pattern of over 6300 genes encoding a broad range of activities. This technology allows quantitative assessment of the change in gene expression between resting and activated cells. To assess the differences in expression of 6300 genes in resting $(0 \mathrm{~h})$ and activated ( 8 and $48 \mathrm{~h}$ poststimulation) $\mathrm{T}$ cells.

\section{Significant findings}

The numbers of genes expressed at 0,8 and $48 \mathrm{~h}$ were remarkably similar. Roughly $7 \%$ of the genes expressed at $0 \mathrm{~h}$ were upregulated by $8 \mathrm{~h}$, with a similar percentage being downregulated. By $48 \mathrm{~h}$ the expression pattern was much closer to resting levels, with only $1.7 \%$ being increased and $0.7 \%$ decreased compared to resting cells. Many of the genes upregulated at $8 \mathrm{~h}$ poststimulation were involved in cell division (eg DNA polymerases and cyclin), whereas transcripts of several antimitotic genes were particularly abundant in resting $\mathrm{T}$ cells. In addition, major differences were found in levels of cytokine receptors, transcription factors and adhesion molecules.

\section{Comments}

The use of microarray technology has many potential uses in rheumatological research. It may be possible in future, for instance, to use this technology to examine gene profiles in arthroscopic samples from inflamed joints and perhaps give clues to diagnosis, prognosis or response to treatment. However 
the generation of such a large amount of data on each sample will require the parallel developments in bioinformatics.

\section{Methods}

T cells were activated in C57BL/10 mice using a V?8 specific superantigen. Mice were sacrificed at 0 $\mathrm{h}, 8 \mathrm{~h}$ and $48 \mathrm{~h}$ and the T cells were purified from lymph nodes. RNA was isolated and cRNA prepared. This was passed over a microarray chip and the relative expression of each gene was compared at the three time points.

\section{References}

1. Teague TK, Hildeman D, Kedl RM, Mitchell T, Rees W, Schaefer BC, Bender J, Kappler J, Marrack P: Activation changes the spectrum but not the diversity of genes expressed by T cells. Proc Natl Acad Sci USA. 2000, 96: 12691-12696. 